\title{
Extrapyramidal side-effects of low-dose aripiprazole in an 11-year-old child
}

\author{
Satyakam Mohapatra \\ Department of Psychiatry, Mental Health Institute, S. C. B. Medical College, Cuttack, Odisha, India
}

\begin{abstract}
Partial agonism of D2 and 5-HT1A receptors accounts for the low incidence of extrapyramidal side-effects of aripiprazole. Extrapyramidal symptoms (EPS) during treatment with therapeutical doses of aripiprazole have been reported in adults and children. To the best of our knowledge, no cases of EPS with low doses $(5 \mathrm{mg})$ have been reported until now. In this article, we present an 11-year-old child who developed EPS on low doses (5 mg) aripiprazole. This case emphasizes the need for careful surveillance for the development of EPS in patients treated even with low doses of aripiprazole.
\end{abstract}

Key words: Aripiprazole, child, extrapyramidal side-effects, low dose

\section{Introduction}

Aripiprazole has been shown to have favorable extrapyramidal symptom (EPS) risk profile in both short-term and long-term randomized double-blind clinical trials. ${ }^{[1]}$ The incidence of EPS and related adverse events is low when compared with other conventional and atypical antipsychotic agents. ${ }^{[2,3]}$ Aripiprazole is a partial agonist of $\mathrm{D} 2$ receptors because of which it exhibits functional dopamine antagonism on hyperactive dopamine neurons and agonistic action in hypodopaminergic conditions. ${ }^{[4]}$ Based on this "unique" mechanism of partial agonistic action, it has a high margin of safety with regard to extrapyramidal side-effects except akathisia, which are comparable to placebo. ${ }^{[5]}$

Aripiprazole is commonly prescribed in the dose range of (10-30) mg in clinical practice. EPS as side-effects of treatment with aripiprazole $10 \mathrm{mg}$ or higher have been previously reported in adults and children.$^{[6-8]}$ However, no cases of EPS with the doses of $5 \mathrm{mg}$ have been reported

\begin{tabular}{|c|l|}
\hline \multicolumn{2}{|c|}{ Access this article online } \\
\hline Quick Response Code: & Website: \\
\hline & www.ruralneuropractice.com \\
\cline { 2 - 3 } & \\
\hline & DOI: \\
\hline
\end{tabular}

until now. We describe a case of 11-year-old child with a diagnosis of acute and transient psychotic disorder who developed EPS on low dose $(5 \mathrm{mg}$ ) aripiprazole.

\section{Case Report}

An 11-year-old boy with uneventful birth and developmental history without past and family history of neurological and psychiatric illness, presented to the outpatient department of Mental Health Institute, SCB Medical College, Cuttack, Odisha, India with complaints of fearfulness, suspiciousness, irritability and decreased sleep for last 7 days. Delusions of persecution were present at the mental status examination. Detailed medical evaluation including neurological examination revealed no significant findings. He was diagnosed to be suffering from acute and transient psychotic disorder, in accordance with International Classification of Diseases-10 $10^{\text {th }}$ Edition criteria. ${ }^{[9]}$ The treatment with aripiprazole $5 \mathrm{mg}$ e.d. and lorazepam $1 \mathrm{mg}$ e.d., was initiated. Two days after the first dose of aripiprazole, the patient developed signs of EPS. He developed stiff and painful arms and legs, tremor of the upper extremities, slurred speech and drooling of saliva. He also presented with parkinsonian gait and cogwheel rigidity. The treatment with aripiprazole was ceased immediately, and given promethazine injection $50 \mathrm{mg}$ i.m. and trihexyphenidyl $4 \mathrm{mg}$ e.d. 1-week after, the patient was almost completely without EPS.

Address for correspondence:

Dr. Satyakam Mohapatra, Senior Resident, Mental Health Institute, S.C.B. Medical College, Cuttack, Odisha, India.

E-mail: satyakgmu@gmail.com 


\section{Discussion}

The incidence of EPS in children treated with aripiprazole is not known. Although aripiprazole is considered one of the safest atypical antipsychotics, the case presented here raise concerns about the EPS potential of aripiprazole. To the best of our knowledge, this is the first case of extra-pyramidal side-effects of aripiprazole in low doses in a patient not previously exposed to other antipsychotics, and with no comorbid medical conditions. We would like to emphasize the need for careful surveillance for the development of EPS in patients treated even with low doses of aripiprazole.

\section{References}

1. Swainston Harrison T, Perry CM. Aripiprazole: A review of its use in schizophrenia and schizoaffective disorder. Drugs 2004;64:1715-36.

2. Jesic MP, Jesic A, Filipovic JB, Zivanovic O. Extrapyramidal syndromes caused by antipsychotics. Med Pregl 2012;65:521-6.
3. Kane JM, Carson WH, Saha AR, McQuade RD, Ingenito GG, Zimbroff DL, et al. Efficacy and safety of aripiprazole and haloperidol versus placebo in patients with schizophrenia and schizoaffective disorder. J Clin Psychiatry 2002;63:763-71.

4. Burris KD, Molski TF, Xu C, Ryan E, Tottori K, Kikuchi T, et al. Aripiprazole, a novel antipsychotic, is a high-affinity partial agonist at human dopamine D2 receptors. J Pharmacol Exp Ther 2002;302:381-9.

5. Mamo D, Graff A, Mizrahi R, Shammi CM, Romeyer F, Kapur S. Differential effects of aripiprazole on $\mathrm{D}(2), 5-\mathrm{HT}(2)$, and 5-HT(1A) receptor occupancy in patients with schizophrenia: A triple tracer PET study. Am J Psychiatry 2007;164:1411-7.

6. Lua LL, Zhang L. Development of Parkinsonism following exposure to aripiprazole: Two case reports. J Med Case Rep 2009;3:6448.

7. Raj L, Mangla D. Aripiprazole induced severe parkinsonian symptoms - A case report. Indian J Psychiatry 2004;46:174-5.

8. Lindsey RL, Kaplan D, Koliatsos V, Walters JK, Sandson NB. Aripiprazole and extrapyramidal symptoms. J Am Acad Child Adolesc Psychiatry 2003;42:1268-9.

9. World Health Organization. The ICD-10 Classification of Mental and Behavioural Disorder, Clinical Description and Diagnostic Guidelines. Geneva: WHO; 1992.

How to cite this article: Mohapatra S. Extrapyramidal side-effects of low-dose aripiprazole in an 11-year-old child. J Neurosci Rural Pract 2016;7:141-2.

Source of Support: Nil. Conflict of Interest: None declared. 